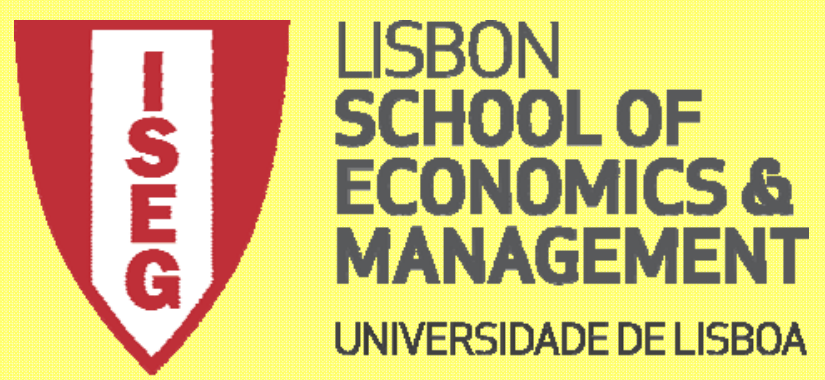

Department of Ec onomics

António Afonso \& Manish K. Singh

Is the supply of long-term debt independent of the term premia? Evidence from Portugal 


\title{
Is the supply of long-term debt independent of the term premia? Evidence from Portugal ${ }^{\text {th }}$
}

\author{
António Afonso $^{\mathrm{a}}$, Manish K. Singh ${ }^{\mathrm{b}, *}$ \\ ${ }^{a}$ Research Unit on Complexity and Economics (UECE) $\mathcal{B}$ Department of Economics \\ Instituto Superior de Economia e Gestão, University of Lisbon, Lisbon, Portugal \\ E-mail address: aafonso@iseg.utr.pt \\ ${ }^{b}$ Department of Economic Theory, University of Barcelona, Barcelona, Spain \\ E-mail: manish.singh@ub.edu
}

\begin{abstract}
An important assumption in the statistical analysis of the financial market effects of the central bank's large scale asset purchase program is that the 'long-term debt stock variables were exogenous to term premia'. We test this assumption for a small open economy in a currency union over the period 2000M3 to 2015M10, via the determinants of shortterm financing relative to long-term financing. Empirical estimations indicate that the maturity composition of debt does not respond to the level of interest rate or to the term structure. These findings suggest a lower adherence to the cost minimization mandate of debt management. However, we find that volatility and relative market size respectively decrease and increase short-term financing relative to long-term financing, while it decreases with an increase in government indebtedness.
\end{abstract}

Keywords: sovereign debt management, long-term interest rate, portfolio balance channel, Bank of Portugal

JEL: E43, E52

\section{Introduction}

Recent studies analyzing the financial market effects of the central bank's large scale asset purchase programs assume that the supply of treasury debt securities are independent of the term premia ${ }^{1}$ (see Eser and Schwaab (2012), Altavilla et al. (2014), Ghysels et al. (2014),

\footnotetext{
This document is a collaborative effort.

*Principal corresponding author. Tel.: +34 666765006; Fax: +34 913942591.

${ }^{1}$ Term premia is defined as the difference between the long-term and short-term interest rate. Throughout this paper, we consider term premia as the difference between the 10-year benchmark Portuguese sovereign bond yield and EONIA (Euro OverNight Index Average). EONIA is the effective overnight reference rate for the euro. It is computed as a weighted average of all overnight unsecured lending transactions in the interbank market, undertaken in the European Union and European Free Trade Association (EFTA) countries. For more detail, refer to European Money Market Institute.
} 
Fratzschser et al. (2014)), ${ }^{2}$ i.e. public debt managers are indifferent to the term premia and do not change the maturity composition of government debt with rising or declining term premia. As long as this assumption holds, i.e. public debt managers do not respond to the term premia in a manner similar to private investors - by selling (buying) less long-term debt when the term premia is high (low) - the estimates of the effect of Central Banks large scale asset purchase programs on the term premia will be biased downward. This justifies the view that the estimates are somewhat conservative (see Gagnon et al. (2011)).

However, what stops the debt managers from raising the maturity of government debt when the term premia is low or is expected to be higher in the future? By issuing more longterm debt securities, managers can lock in the current lower interest rates. Higher future interest rates may also go hand in hand with higher rollover risk if the average debt maturity is too short. Therefore, the legal mandate of cost minimization and risk considerations must lead debt managers to raise the maturity today if they expect term premia to be higher and market conditions more difficult in the future (see Chadha et al. (2013)).

Similarly, debt managers should reduce the maturity when the term premia is high or is expected to be lower in the future. Shortening maturities today would reduce cost immediately as the term premia is normally positive. At the same time, rollover risks are smaller if debt managers hold the view that future term premia will be lower. These considerations regarding the potential amplifying behavior of debt managers run counter with comments made in the previously cited studies.

Therefore, to understand the debt issuance behavior, we empirically investigates the evolution of sovereign debt maturity composition for the Portuguese economy. Our focus here is the 2000M3-2015M10 period. We classify this period into three distinct phases. The first phase 2000M3-2008M8 is considered as the pre-crisis period. This period preceding the start of the global financial crisis improves the chance of identifying the supply effects of treasury debt, which would otherwise be obfuscated by other factors. ${ }^{3}$

The second phase (2008M9-2011M3) was the period following the collapse of Lehman Brothers till the period when Portugal officially declared loss of market access ${ }^{4}$ and decided to join the Economic Adjustment Program. The rest of the period falls under the three-year economic adjustment program that was signed in May 2011 by the Portuguese Government and the European Commission on behalf of the troika. ${ }^{5}$

\footnotetext{
${ }^{2}$ For the US, see Gagnon et al. (2011), D'Amico and King (2010), Hamilton and Wu (2011), Stroebel and Taylor (2012), Rosa (2012), Wright (2012); For the UK, see Joyce et al. (2011); For global market, see Leduc and Glick (2012).

${ }^{3}$ The difficult financial market conditions prevailing in the post-crisis period, capital constraints on banks and other financial firms, worries about the creditworthiness of sovereigns and wholesale market counterparties, and uncertainty about future regulations would all inhibit arbitrage by the private sector. Fiscal support to financial and real sector by the government, loss of market access and direct ECB interventions in the sovereign debt markets directly interferes with the actions of debt managers.

${ }^{4}$ For instance Afonso (2013) mentions 'The unstoppable vicious circle of rising long-term government bond yields and sovereign downgrades, that preceded the request for financial support in 2011.'

${ }^{5}$ Troika is the tripartite committee led by the European Commission with the European Central Bank and the International Monetary Fund, that organized loans to the governments of Greece, Ireland, Portugal, and Cyprus.
} 
We address the following questions: (1) Is the supply of long-term treasury debt securities independent of the term premia? In other words, are debt managers indifferent to movements in sovereign bonds yields; and (2) What factors influence the debt managers behavior in adjusting the maturity composition of government debt?

Our results suggest that the maturity composition of debt does not respond to the level of interest rate or to the term premia. This finding give support to the recent claims that the effect of large scale asset purchase program of sovereign debt securites are somewhat conservative (see Gagnon et al. (2011), Eser and Schwaab (2012), Altavilla et al. (2014), Ghysels et al. (2014), Fratzschser et al. (2014)). We also find that volatility and relative market size respectively decrease and increase short-term financing relative to long-term financing, while it decreases with an increase in government indebtedness - suggesting debt managers adherence to the cost minimization mandate during calm periods. The significant influence of relative debt market size and cross-border holding of public debt during calm as well as crisis period suggest liquidity concerns as the major factor determining the evolution of maturity composition over time.

The remainder of the paper is structured as follows. Section 2 discusses the objectives and evolution of public debt management in theory and practice. Section 3 provides an overview of our country and time period selection. Section 4 builds hypothesis regarding the debt managers' behavior and provide some visual evidence. Section 5 investigates Portuguese public debt managers behavior (i.e. maturity composition decisions) based on estimations of reaction functions. Section 6 summarizes the results while Section 7 concludes with a few policy recommendations.

\section{Public debt management}

Public debt management is defined as open market operations carried out in order to change the composition of the outstanding stock of government-issued debt instruments. The composition of public debt is usually characterized by the outstanding debt's maturity structure and public debt management is mainly concerned with changes in the maturity structure. The distinction between the effects due to public debt management and the effects due to fiscal policy is that the public debt management has to be self-financed. This means that if the government purchases one type of government-issued bond it simultaneously has to issue other types of bonds in order to finance the purchase without affecting the level of government expenditure.

The early literature on public debt management evolved around the understanding of key principles appropriate for the public debt management. Public debt was looked upon as provider of utility to government and different maturity combinations were considered as providing same utility at different costs. Minimization of the government's interest costs was considered the main objective as this rationale implies minimization of the taxes needed to finance sovereign debt and hence minimization of the excess burden of taxation, contributing also to efficiency gains (see notably Cohen (1955), Rolph (1957), and Afonso and Gaspar $(2007))$. 
However public debt management as a tool for economic policy took shape when inquiries by Musgrave (1959) and in particular Tobin (1963) showed that the government can also affect the economic activity through public debt management, i.e., public debt management could be used as an instrument in stabilization policy. Based on the relative substitutability of money, government bonds and real capital in the public's aggregate portfolio, government's choice of debt instrument can crowd-in or crowd-out private investment. To induce private investment, government should reduce the supply of government issued bonds which are close substitute to corporate equity and issue bonds that are distant substitutes. This will increase the demand for corporate equity and hence lowers the firms' costs of capital, which increases (crowds-in) private investment.

In the same vein, Roley (1979), and Agell and Persson (1992), using the atemporal capital asset pricing model developed by Sharpe (1964) and Lintner (1965) showed that the public debt managers can influence economic activity depending on the covariances of the government-issued bonds' returns with the returns on private capital. By changing the supply of government-issued bonds with different covariances, the government can affect the relative asset yields. The changes in relative asset yields affect the valuation of corporate equity and hence the cost of capital, which in turn affects the investments. Accordingly, public debt management was seen as an extension of monetary and/or fiscal policy and was often in the hands of either fiscal or monetary authorities. ${ }^{6}$

However since the late 1980s, the institutional setting for public debt management has undergone a strong transformation. During the 70's and 80's, most countries ran almost permanent budget deficits and funded these deficits with new types of debt instruments, deregulated financial markets or opted for direct debt monetization (by running huge inflation). This raised serious concerns regarding the debt sustainability, inflation and the inherent trade-offs. ${ }^{7}$ The acknowledgment of this inherent conflicts of interest and increased understanding that different policy objectives are best achieved by independent authorities paved the way for independent public debt management and monetary policy authority.

However since the outbreak of the global financial crisis and European sovereign debt crisis, the need for short run stimulation is pressing. Hence, when monetary policy is nonaccommodative, within limits debt management policy can take its place in augmenting the potency of fiscal policy, or in improving the trade-off between short-run stimulation and investment for long-run growth (see Tobin (1969), Friedman (1978)).

\section{Empirical studies}

\footnotetext{
${ }^{6}$ Other aspects of debt management have also been discussed in the literature. Chan (1983), for example, discusses the conditions under which the composition of the outstanding public debt is irrelevant, i.e., when public debt management is neutral. Gale (1990) discusses the welfare issues of public debt management, in particular the impact of public debt management on the efficiency of risk sharing.

7 The argument goes that if the monetary authority is responsible for both monetary policy and public debt management, it might be hesitant to raise interest rates to control inflationary pressures or be tempted to lower interest rates in order to constrain debt servicing costs. This would obviously go at the expense of the price stability objective, if, for instance, the central bank would also need to decide on the issuance of Treasury Bills.
} 
There have also been a number of empirical studies of the effects of public debt management, which provide mixed evidence on the effects of public debt management. Modigliani and Sutch (1967) study the effects of Operation Twist, which was carried out in 1961 by the Federal Reserve System in the United States. Operation Twist aimed at shortening the average maturity of the outstanding public debt in order to raise the short-term interest rates and lower the long-term interest rates. Modigliani and Sutch (1967) find no or weak evidence of effects on the term structure of interest rates. Agell and Persson (1992) empirically analyze the effects of public debt management on the financial markets using an atemporal capital asset pricing model. They estimate the covariance matrix of asset yields using US data and find that public debt management affects the relative asset yields. However, they find these effects too small to have any impact on the real economy. Friedman (1992) uses US data and a general equilibrium framework where the financial markets are modeled in essentially the same way as in Agell and Persson (1992). He finds that public debt management has effects on the relative asset yields and on the real economy.

\section{The case of Portugal}

A priori, capturing debt management behavior in an econometric model does not seem an easy task. When assessing the link between debt management behavior and term premia, we face the issue of potential endogeneity. Furthermore, debt offices issue a wide array of instruments, for example index linked or nominal bonds, with fixed or floating rates, and/or denominated in national or foreign currency. Issuance decisions may reflect several demand and supply factors, which may be potentially difficult to disentangle (see Hoogduin et al. (2010)).

We therefore simplify our approach by selecting a small open economy, Portugal, within a currency union and study debt managers' behavior for a relatively calm period. This choice rules out a few complexities and allows us to use more advanced specifications to understand debt managers' behavior. ${ }^{8}$ From the advent of euro, Portuguese debt management has gone through very important changes. At the institutional level, a new public debt law was approved for the creation of an autonomous debt agency and formal guidelines were defined. A series of reforms took place that aimed to develop conditions for a more efficient management of public debt in this new environment.

As part of the European Economic and Monetary Union, the Portuguese government adopted the euro as its official currency and benefited from the credibility of a monetary policy (though lost the option to monetize the debt) that is defined at the EU level. This makes the Portuguese public debt management almost completely independent from the monetary policy objectives which are set at the pan European level. Also the privileged position as the reference issuer in the Portuguese escudo ${ }^{9}$ was lost and Portugal became a

\footnotetext{
${ }^{8}$ An important caveat as noted in Hoogduin et al. (2010) is that the estimations only capture issuance policy, which is highly observable to the market. The estimations do not capture how debt managers subsequently influence the maturity profiles of their debt through the use of financial derivatives, on which data availability is rather limited.

${ }^{9}$ Escudo was the Portuguese currency prior to joining euro.
} 
small borrower in a large market, where it has to compete with other sovereign issuers (e.g., Austria, Greece) for the same investor base. Concerns with the liquidity of government debt led the public debt managers towards progressive concentration of the financing activity into the issuance of a restricted number of standard fixed rate euro denominated Treasury bonds (OT). Commercial paper and savings certificates (a retail instrument sold to individuals) has been phased out gradually though they still exist in the portfolio. Since joining the euro, open market operations are extensively used to restructure the portfolio of existing debt into larger and more liquid treasury debt issues.

\subsection{Portuguese public debt management}

Set up in December 1996, the Agência de Gestão da Tesouraria e da Dívida Pública -IGCP is an autonomous institution responsible for the management of the Portuguese central government debt and the execution of the central government borrowing program, in accordance with the law and the guidelines defined by the government. The strategic objectives explicitly state that public debt managers should aim to guarantee the financial resources required for the execution of the state budget and be conducted in such a way as to:

1. Minimize the direct and indirect cost of public debt on a long-term perspective;

2. Guarantee a balanced distribution of debt costs through the several annual budgets;

3. Prevent an excessive temporal concentration of redemptions;

4. Avoid excessive risks (namely refinancing risk and the debt volatility cost over time);

5. Promote an efficient and balanced functioning of financial markets.

As can be read, no explicit macroeconomic considerations or objectives are defined as being part of the debt management. The idea was to make debt management very similar to portfolio debt manager. However, the objectives left open the planning horizon of debt management. This seemingly minor difference blurs the line where macroeconomic circumstances could outweigh cost considerations and can lead to considerable differences in the practices of debt managers.

\subsection{Fiscal position}

Portugal got a good start in the run-up to the euro. The fiscal deficit improved from above $5 \%$ of GDP in 1995 to just over $3 \%$ in 1999, the general government debt (as \% of GDP) dropped from $60 \%$ to just over $50 \%$ and the benchmark 10-year Portuguese sovereign bond yield dropped from around $12 \%$ to less than $4 \%$. These developments helped satisfy the fiscal rules introduced in the Maastricht Treaty and the Stability and Growth Pact (SGP) in the early and mid-1990s (Figure 1).

[Figure 1 about here.]

However it didn't fully observe the fiscal discipline that EU members have to comply with. After the euro had been introduced, the fiscal situation started deteriorating. The 
general government gross debt started showing a continuous upward trend (crossed the 1995 level by 2003 and stayed above) even when the cost of borrowing remained at its lowest level. The government net borrowing requirement also reached the pre-euro 5-year average level by 2005 and overshot both the general government gross debt and deficit targets by the end of year 2004. Since the onset of the global financial crisis, the fiscal positions have further deteriorated significantly and accentuated the sovereign risk level.

\section{What explains debt managers' behavior?}

In this section, we try to understand the determinants of debt managers' behavior and build some testable hypothesis. We also document the additional drivers whose relevance will vary during different phases. As per the norm, at the start of the year, debt manages get an estimate of debt financing requirement by the government. Once this information is available, the following decisions need to be made: (1) the maturity composition of debt; and (2) the timing of debt issuance. The economic question we want to raise here is how these decisions are influenced by the yield curve. We closely follow Hoogduin et al. (2010) and try to build debt managers reaction function along similar lines. With our dependent variable - short-term financing relative to long-term financing $\left(R_{S L}\right)^{10}$ - we aim to capture the core policy decision of debt managers, namely deciding on the maturity. This ratio is also relevant for the extent to which debt management interacts with central bank policy decisions related with financial stability and monetary policy.

\subsection{Data visualization}

A preliminary look at the data provides some suggestive evidence of the role of yield curve in debt managers' reaction function. Figure 2 plots $R_{S L}$ (ratio of short to long-term debt) with the money market rate (short-term interest rate). As can be seen, during the first phase, the ratio of short-term debt increases in general when the policy rate goes down, suggesting more short-term debt issuance. However in the second phase, the average share of short-term debt becomes extremely high. After joining the Economic Adjustment Program, this trend breaks but once Portugal started getting market access, it restores the trend.

[Figure 2 about here.]

Figure 3 plots $R_{S L}$ with 10-year benchmark Portuguese sovereign bond yield. In general, the share of short-term debt increases even when the long-term interest rates falls (movement in opposite direction). This is counterintuitive as fall in long-term interest rate should help debt managers raise long-term debt comfortably. To help understand this, we plot term premia with $R_{S L}$ in Figure 4 . When the term premium is low, we observe lower $R_{S L}$ suggesting long-term debt issuance compare to short-term which translates to lower $R_{S L}$ (movement in similar direction).

[Figure 3 about here.]

[Figure 4 about here.]

\footnotetext{
${ }^{10}$ The detailed variable construction methodology is explained in section 5 .
} 


\subsection{Hypothesis on the behavior of public debt managers}

The variable of interest, our dependent variable is the ratio of short-term to long-term debt $\left(R_{S L}\right)$. We expect this ratio to be driven by the following variables:

1. Net financing need: As debt managers ensure that the financing needs of the government are met, the primary fiscal deficit will play an important role. Assuming the predictability of debt issuance vital for debt market, higher financing needs will make debt managers shift the portfolio towards long-term maturities given the expected increase in long-term interest rate;

2. Current debt level: Higher outstanding sovereign debt amounts could imply that a lower fraction should be financed in the money market in order to limit exposure to interest rate shocks, forcing the debt managers towards the longer maturity;

3. A benchmark debt composition: For wholesale development of short and long-term debt market, we expect debt managers to always finance at least a minimum fixed amount of their financing needs in the money market;

4. Cost factors: Cost considerations will be reflected by the current and expected levels of short-term and long-term interest rates. A higher short-term interest rate implies more expensive money market financing and may decrease the share of short-term financing. However higher expected short-term rate will increase the share of shortterm financing;

5. Risk factors: Current market volatility and term premia relative to the historical average will reflect the risk considerations. During periods of heightened volatility, it might be more difficult to issue long-term bonds. Likewise, in an inflationary environment, investors might opt for short-term positions, leading to a positive effect;

6. Liquidity: Size and credit quality, relative to the size and credit quality of the European debt market matters for higher liquidity. Higher liquidity will help tap long-term investors making it easier to raise long-term debt.

As can be seen (Figures 2-4), the $R_{S L}$ responds in the expected direction for short-term interest rates and term premia but not to the long-term interest rate. We also see some sudden reversal in the direction of movement. The purposes of our empirical analysis is thus to explain these movements over time and to test whether the drivers remain the same throughout the sample period.

\section{Data and empirical methodology}

\subsection{Data}

Dependent variable: Our dependent variable is the ratio of outstanding short-term to long-term government debt. This data is not available at monthly frequency. So to calculate the debt stock at monthly frequency, we use two separate dataset: (1) Dataset 1: General government short and long-term gross debt variable which is available at quarterly frequency; and (2) Dataset 2: Net issues of general government short, long and total debt securities which is available at monthly frequency. Since Dataset 1 is available starting 31-03-2000, 
we take the general government short and long-term gross debt as on 31-03-2000 as the debt stock. The monthly debt stock variable is then computed by subtracting/adding (for period pre/post 31-03-2000) monthly net debt issues (Dataset 2) from the debt stock. To cross check the computed values, we compare our monthly data with the net stock of debt outstanding every quarter end and find numbers very close to figures available in Dataset 1.

Explanatory variables: The set of explanatory variables focuses on six types of variables: (i) The short-term interest rate which is proxied by the money market rate (EONIA); (ii) The long-term interest rate is proxied by 10-year benchmark Portuguese sovereign bond yield; (iii) The current period uncertainty is proxied by the annualized 10-year sovereign bond market volatility; (iv) Sovereign fiscal position is proxied by the general government debtto-GDP and net borrowing to GDP ratio; (v) The size of the Portuguese government debt market relative to the European debt market and foreign holding of Portuguese government debt is used as proxies for the liquidity concerns. A detailed list of variables, the data source, measurement unit and frequency is summarized in Table 1 while Table 2 provides the summary statistics.

[Table 1 about here.]

[Table 2 about here.]

\subsection{Econometric specification}

We take as a starting point in our analysis the empirical specification suggested by Hoogduin et al. (2010) and estimate the following debt management reaction function using OLS for the Portuguese economy:

$$
\begin{aligned}
& \Delta R_{t}^{S L}=c+\alpha_{1} \text { EONI }_{t-1}+\alpha_{2} \text { Term Spread } \text { Se }_{t-1}+\alpha_{3} \text { Volatility }_{t-1}+\alpha_{5}(\text { Debt } / G D P)_{t-1} \\
& \quad+\alpha_{6} \text { Primary deficit } \text { Pr-1 }_{t-1}+\alpha_{7} \text { Relative size } \text { R }_{t-1}+\alpha_{9} \text { Foreign holding }_{t-1}+\delta \Delta R_{t-1}^{S L}+\epsilon_{t}
\end{aligned}
$$

where, subscript t stands for time; EONIA: Month-end Euro Overnight Index Average; Term spread: Month end term spread (difference between 10 year benchmark Portuguese bond yield and EONIA); Volatility: Monthly historical annualized volatility based on 10Y benchmark sovereign bond yields; Debt/GDP: Debt-to-GDP ratio at the end of last quarter; Primary deficit: Difference between the general government expenditure and revenue as percentage of GDP at the end of each quarter; Relative size: Portuguese bond market size relative to the Eurozone debt market; and Foreign holding: Non-resident holding of Portuguese sovereign debt. Table 2 provides the summary statistics of the variables. ${ }^{11}$

Moreover, the effects of special events that possibly influence financing decisions are captured by dummies. Finally, we expect a statistically significant coefficient for the lagged dependent variable since a high outstanding short-term debt by the end of a period implies that a large fraction of it will have to be refinanced in the following period.

\footnotetext{
${ }^{11}$ Our dependent variable exhibits non-stationary behavior and hence we use first difference $\left(\Delta R_{S L}\right)$. The non-stationarity results are not shown here but is available upon request.
} 
Our analysis differs from other studies as our focus is on the maturity structure of government debt held outside the central bank, which can be affected by the operation of both the central bank and the fiscal agency. The aim is to estimate debt amangers reaction function in normal times during the calm period and before the ECB started intervening massively. The estimation period therefore only covers the pre-crisis period during which the central bank was not seeking to influence the term premia directly. These estimates should not be contaminated by the special effects of recent central bank intervention, regulatory changes and safe-haven flows on long-term interest rates.

\section{Results}

Table 3 shows the raw correlation between the explanatory variables with $R^{S L}$. Shortterm interest rate is strongly and negatively correlated with $R^{S L}$ which is in line with the expected behavior of debt managers. The term spread and market volatility is positively correlated which suggest higher short term debt issuance when risk and uncertainty is high. The sovereigns fiscal positions are also positively correlated with $R^{S L}$ suggesting higher issuance of debt increases the share of short-term debt. Relative debt market size and foreign holding of debt is very strongly and positively correlated with $R^{S L}$ suggesting the role of safe heaven flows during turbulent times.

\section{[Table 3 about here.]}

Table 4 shows the baseline OLS estimates using Equation (1). An important assumption in the our statistical analysis is the Portuguese sovereign yield were exogenous to the debt managers behavior during this period. This assumption implies that short-term and longterm interest rates were not influenced by the issuances of short or long-term debt, i.e., the Portuguese debt managers took interest rates as given and were able to influence only the maturity composition. We believe that this is a reasonable assumption as during this period, the Euro area sovereign debt market yield were completely in line with the German government yield and were driven primarily by the world market conditions.

The conditional correlations shows a very different picture than what we observe with raw correlations. The sign of the intercept coefficient is negative and statistical insignificance. This is a bit puzzling as it suggests that debt managers do not target a benchmark debt composition where a certain proportion of debt is always raised in the short-term debt market. One possible reason for this may be the strong focus of Portuguese debt managers to establish long-term debt market in Portuguese benchmark bonds (10-years). As the debt market of Portuguese bond is relatively small in the European context, it may be more advantageous for debt managers to issue bonds in higher denominations.

\section{[Table 4 about here.]}

Also during calm period, the $R^{S L}$ is strongly and positively influenced by the short-term money market rate. This is counterintuitive as this suggests issuance of more short-term debt when short-term rates go up. We find the effect of term premia insignificant while 
market volatility is significantly and positively correlated with $R^{S L}$. The share of short term financing, apart from a relevant stickiness effect of the lagged endogenous variable, increases with an increase in government indebtedness. This debt effect can imply that higher level of government debt ratio decreases the average debt maturity, i.e. debt managers find it difficult to raise the outstanding debt duration when government indebtedness is high. We also find negative and significant effect of primary deficit on $R^{S L}$.

The effect of liquidity variables are extremely pronounced and significant. The Portuguese debt market size relative to Eurozone debt market negatively influence $R^{S L}$ suggesting the competitiveness and difficulties associated with the issuance of high amount of debt. The effect of foreign debt holding is positive suggesting risk averse behavior of foreign debt holders towards long term Portuguese sovereign debt. Moreover, we would indeed expect a statistically significant negative coefficient for the lagged dependent variable since a high outstanding short term debt by the period implies that the debt managers would need to rebalance the portfolio in the following period.

\subsection{Crisis period}

When we estimate the full sample and crisis period to contract this with the pre-crisis period (first and the last column in Table 4), we see that most variables loose their significant. The debt ratio becomes irrelevant in the crisis period as a determinant of the relative size of the short-term financing. Moreover, even the statistically significant coefficient for the lagged dependent variable becomes insignificant suggesting the role of other exogenous variables in determining the share of short-term debt.

On the other hand foreign debt holding of sovereign debt pushes up the share of shortterm debt in the pre-crisis and in the full time period. For the full period, show that the share of short term financing, apart from a relevant stickiness effect of the lagged endogenous variable, decreases with an increase in government indebtedness. This debt effect can imply that the higher the level of government debt ratio the more the authorities wish to increase the average maturity (and the duration) of the stock of sovereign debt liabilities. A similar result emerges for the primary deficit ratio.

In addition, the relative market size seems to be detrimental to the share of shortterm debt, what can be explained by the fact the smaller sovereign debt markets may lack higher degrees of liquidity. Nevertheless, after the last quarter of 2008, in the crisis period, this determinant is not statistically relevant, as is in fact the case for all other tentative determinants. Interestingly, in the crisis period, higher volatility in the sovereign market 10-year yield increased the relative size of short-term debt, hinting to the fact that capital markets have shied away from long-term debt issuances by Portugal, and also that during the adjustment program the sovereign financing was relying of the IMF/EC financial support.

In Table 5 we report a set of results with interaction terms for the crisis. In this context we see that volatility and relative market size respectively decrease and increase shortterm financing relative to long-term financing. In addition, the term-spread, the difference between the 10-year sovereign yield for Portugal and EONIA, is positively determining the relative size of short-term debt. 
[Table 5 about here.]

In order to assess and take into account the possibility of endogeneity we report in Table 6 the estimation results for a baseline specification using 2SLS. The conclusions hold as we can see when comparing with the results from Tables 4 and 5 . In practice the fiscal and the foreign debt ownership determinants are still paramount as is the case of the term-spread for the dummy-crisis version of the estimation.

\section{[Table 6 about here.]}

\subsection{Robustness checks}

Firstly, the results are robust to different measures of short-term (EURIBOR or 3-month treasury yield or Marginal lending rate) and long-term interest rate (2-year, 5-year or 10-year Portuguese sovereign yield). Secondly, we made an exercise of robustness and checked to what extent economic fundamentals play a role, notably publicly available macroeconomic forecasts from the European Commission, published in the Spring and in the Autumn.

We use a different econometric setup to gain some intuition on the role that debt managers' can play. We assume that the debt managers are forward looking and their behavior response to changes in macroeconomic environment. To estimate this model specification, we expand the set of explanatory variable focusing on three types of variables noted below: (i) the expected macroeconomic conditions; (ii) expected sovereigns fiscal position; and (iii) the uncertainty about the economic fundamentals. In particular, the following variables are included to capture the expected macroeconomic and fiscal state: GDP growth forecast; expected inflation; expected unemployment rate; expected Debt-to-GDP ratio. All variables are calculated as the average of the forward two year forecast available from European Commissions website. ${ }^{12}$

More precisely, we try to estimate the following specification:

$$
\begin{array}{r}
\Delta R_{t}^{S L}=c+\alpha_{1} \text { EONIA }_{t-1}+\alpha_{2} \text { Term Spread }_{t-1}+\alpha_{3} \text { Volatility }_{t-1}+\alpha_{4} \text { Primary Deficit }_{t-1} \\
+\alpha_{7} \text { Relativesize }_{t-1}+\alpha_{9} \text { Foreign holding }_{t-1}+\delta R_{t-1}^{S L}+\beta_{1} E_{t}\left\{G D P G R_{t+s}\right\} \\
+\beta_{2} E_{t}\left\{U N E M P_{t+s}\right\}+\beta_{3} E_{t}\left\{I N F_{t+s}\right\}+\beta_{4} E_{t}\left\{D E B T G D P_{t+s}\right\}+\epsilon_{t}
\end{array}
$$

where, $G D P G R_{t+s}$ is the year end expected future growth rate; $U N E M P_{t+s}$ is the year end expected unemployment rate; $I N F_{t+s}$ is the expected yearly inflation and $D E B T G D P_{t+s}$ is the expected year end gross debt. We estimate the model on monthly data over the entire sample period. ${ }^{13}$

\footnotetext{
${ }^{12}$ DG ECFIN produces these economic forecasts on behalf of the European Commission and are published in the spring and autumn.

${ }^{13}$ An alternative specification is also tried to capture the uncertainty regarding economic fundamentals: (i) Economic sentiment indicator (ESI); (ii) Industrial confidence indicator (ICI); and (iii) Consumer confidence indicator. All these indices are built and maintained by EC and the seasonally adjusted data is available at monthly frequency. Our regression estimates suggest similar findings. The results are not included here to save the space but is available upon request.
} 
Although the results in Tables 7 and 8 do not provide additional statistically significant insights for such potential determinants, the forecasts for the debt ratio show up as important in one instance (Table 8), and in line with the previous results for the debt ratio itself. A similar conclusion is possible for the forecasted debt ratio using a 2SLS approach (Table 9). Therefore, higher expected debt ratios, via the EC forecasts, the lower would be the share of short-term debt.

$$
\begin{aligned}
& \text { [Table } 7 \text { about here.] } \\
& \text { [Table } 8 \text { about here.] } \\
& \text { [Table } 9 \text { about here.] }
\end{aligned}
$$

\section{Conclusion}

In this paper we have assessed the assumption that the treasury supply of long-term debt is independent of the term premium for a small open economy in a currency union over the period 2000M3 to 2015M10, via the determinants of short-term financing relative to long-term financing. Empirical estimations indicate that the maturity composition of debt does not respond to the level of interest rate or to the term premia. These findings give support to the claims made by recent papers that the effect of large scale asset purchase program of sovereign debt securites are somewhat conservative (see Gagnon et al. (2011), Eser and Schwaab (2012), Altavilla et al. (2014), Ghysels et al. (2014), Fratzschser et al. (2014)).

Our result also suggest that volatility and relative market size respectively decrease and increase short-term financing relative to long-term financing, while it decreases with an increase in government indebtedness - suggesting debt managers adherence to the cost minimization mandate during calm periods. The significant influence of relative debt market size and cross-border holding of public debt during calm as well as crisis period suggest liquidity concerns as the major factor determining the evolution of maturity composition over time.

Moreover, in the crisis period, more volatile Portuguese sovereign 10-year yields increased the relative supply of short-term debt, with investors not wishing the respective long-term debt. Increasing the supply of short-term debt increased the interaction between public debt management and monetary policy. Excessive issuance of debt signaled deteriorating public finances while excessive short-term debt issuance increased the refinancing risk. As the bad market conditions persisted, this translated into loss of market access. In practice, during the adjustment program sovereign financing was essentially done with IMF/EC financial support and some short-term Treasury Bills issuance.

Regarding policy implications it would be advisable to issue more long term debt when the market conditions are favorable to create a relevant stock of sovereign fund, which can be used when the market tightens. In the crisis scenario where central bank directly purchases government bonds in the secondary market as part of the unconventional monetary policies, the public debt managers' behavior can undermine or even reverse the financial stability gains. 


\section{Acknowledgments}

We thank Simón Sosvilla-Rivero and Marta Gómez-Puig for helpful suggestions. This paper is based upon work supported by the Government of Spain and FEDER under grant number ECO2011-23189. Manish K. Singh thanks the UECE, University of Lisbon for their hospitality. The opinions expressed herein are those of the authors and do not necessarily reflect those of their employers. Any remaining errors are the authors' sole responsibility.

\section{References}

Afonso, A., 2013. Anatomy of a fiscal debacle: the case of Portugal. Department of Economics, ISEG-UL, WP $01 / 2013 /$ DE/UECE.

Afonso, A., Gaspar, V., 2007. Dupuit, Pigou and cost of inefficiency in public services provision. Public Choice 132 (3-4), 485-502.

Agell, J., Persson, M., 1992. Does debt management matter? in: J. Agell, M. Persson, and B.M. Friedman, Does Debt Management Matter?, FIEF Studies in Labour Markets and Economic Policy, Clarendon Press, Oxford.

Altavilla, C., Giannone, D., Lenza, M., 2014. The financial and macroeconomic effects of the OMT announcements. ECB Working Paper.

Angeletos, G., 2002. Fiscal policy with non-contingent debt and the optimal maturity structure. Quarterly Journal of Economics (117), 1105-1131.

Barclay, M. J., Clifford, W. S. J., 1995. The maturity structure of corporate debt. Journal of Finance 50, 609-631.

Barro, R. J., 1995. Optimal debt management. NBER Working paper (5327).

Blommestein, H. J., Gok, A., 2009. The surge in borrowing needs of OECD governments: Revised estimates for 2009 and 2010 outlook. OECD Journal: Financial Market Trends.

Butler, A. W., Grullon, G., Weston, J. P., 2006. Can managers successfully time the maturity structure of their debt? Journal of Finance 61, 1731-1758.

Chadha, J., Turner, P., Zampolli, F., 2013. The interest rate effects of government debt maturity. Working paper, Bank of International Settlement (415).

Chan, L. K. C., 1983. Uncertainty and the neutrality of government financing policy. Journal of Monetary Economics 11, 351-372.

Cochrane, J. H., Piazzesi, M., 2005. Bond risk premia. American Economic Review 95, 138-160.

Cohen, J., 1955. A theoretical framework for treasury debt management. American Economic Review 45, 320-344.

D'Amico, S., King, T. B., 2010. Flow and stock effect of large scale treasury purchases. Federal Reserve Board Finance and Economics Discussion Series (2010-52).

Diamond, D. W., 1991. Debt maturity structure and liquidity risk. Quarterly Journal of Economics 106, 709-737.

Dornbusch, R., Draghi, M., 1990. Public Debt Management: Theory and History. Center for Economic Policy Research, Cambridge University Press, Cambridge, Great Britain.

Eser, F., Schwaab, B., 2012. The yield impact of central bank asset purchases: the case of the ECB's Securities Markets Programme. European Central Bank, mimeo.

Fratzschser, M., Lo Duca, M., Straub, R., 2014. ECB unconventional monetary policy actions: Market impact, international spillovers and transmission channels. Paper presented at the 15th Jacques Polak Annual Research Conference.

Friedman, B. M., 1978. Crowding out or crowding in? The economic consequences of financing government deficits. Brookings Papers on Economic Activity 3, 593-654.

Friedman, B. M., 1992. Debt management policy, interest rates and economic activity. in: J.. Agell, M. Persson, and B.M. Friedman, Does Debt Management Matter?, FIEF Studies in Labour Markets and Economic Policy, Clarendon Press, Oxford. 
Gagnon, J., Raskin, M., Remache, J., Sack, B., 2011. The financial market effect of federal reserve's largescale asset purchases. International Journal of Central Banking 7 (1), 3-43.

Gale, D., 1990. The efficient design of public debt. in: R. Dornbusch and M. Draghi, editors, Public Debt Management: Theory and History, Center for Economic Policy Research, Cambridge University Press, Carrlbridge, Great Britain.

Garbade, K. D., 2007. The emergence of 'regular and predictable' as a treasury debt management strategy. Federal Reserve Bank of New York, Economic Policy Review 13, 53-71.

Ghysels, E., Idier, J., Manganelli, S., Vergote, O., 2014. A high frequency assessment of the ECB Securities Markets Programme. Working Paper, European Central Bank (1642).

Greenwood, R., Vayanos, D., 2010. Price pressure in the government bond market. American Economic Review 100.

Guibaud, S., Nosbusch, Y., Vayanos, D., 2007. Preferred habitat and the optimal maturity structure of government debt. Working Paper, London School of Economics.

Hamilton, J., Wu, J., 2011. The effectiveness of alternative monetary policy tools in a zero lower bound environment. Journal of Money, Credit, and Banking 44, 3-46.

Hoogduin, L., Öztürk, B., Wierts, P., 2010. Public debt managers' behaviour: Interactions with macro policies. Working paper, De Nederlandsche Bank (273).

Joyce, M. A. S., Lasaosa, A., Stevens, I., Tong, M., 2011. The financial market impact of quantitative easing in the United Kingdom. International Journal of Central Banking 7 (3), 113-162.

Krishnamurthy, A., Vissing-Jorgensen, A., 2011. The effects of quantitative easing on interest rates: channels and implications for policy. Brookings Papers on Economic Activity 2, 2015-287.

Leduc, S., Glick, R., 2012. Central bank announcements of asset purchases and the impact on global financial and commodity markets. Journal of International Money and Finance 31 (8), 2078-2101.

Lintner, J., 1965. The valuation of risk assets and the selection of investments in stock portfolios and capital budgets. The Review of Economics and Statistics 47, 13-37.

Modigliani, F., Sutch, R., 1967. Debt management and the term structure of interest rates: An empirical analysis of recent experience. Journal of Political Economy 75, 569-589.

Musgrave, R. A., 1959. The Theory of Public Finance. McGraw-Hill Book Company, New York.

Roley, V. V., 1979. A theory of federal debt management. American Economic Review 69, 915-926.

Rolph, E. R., 1957. Principles of debt management. American Economic Review 47, 302-320.

Rosa, C., 2012. How 'unconventional' are large-scale asset purchases? The impact of monetary policy on asset prices. Federal Reserve Bank of New York, Staff report (560).

Sharpe, W. F., 1964. Capital asset prices: A theory of market equilibrium under conditions of risk. Journal of Finance 19, 425-442.

Stein, J. C., 1989. Efficient capital markets, inefficient firms: A model of myopic corporate behavior. Quarterly Journal of Economics 104, 655-669.

Stroebel, J., Taylor, J., 2012. Estimated impact of the federal reserve's mortgage-backed securities purchase program. International Journal of Central Banking 8 (2), 1-42.

Tobin, J., 1963. An essay on the principles of debt management. in J. Tobin, Fiscal and Debt Management Policies, Prentice Hall, Englewood Cliffs, New Jersey. Reprinted in Tobin (1971).

Tobin, J., 1969. A general equilibrium approach to monetary theory. Journal of Money, Credit, and Banking $1,15-29$.

Tobin, J., 1971. Essays in Economics Volume 1: Macroeconomics. Markham Publishing Company, Chicago.

Vayanos, D., Vila, J., 2009. A preferred-habitat model of the term structure of interest rates. Working Paper, London School of Economics.

Wright, J., 2012. What does monetary policy do to long term interest rates at the lower zero bound? Economic Journal 122, 447-466. 
Figure 1: Portuguese general government statistics

Source: Eurostat; REUTERS. The horizontal lines in Figure (a) represents SGP limits.

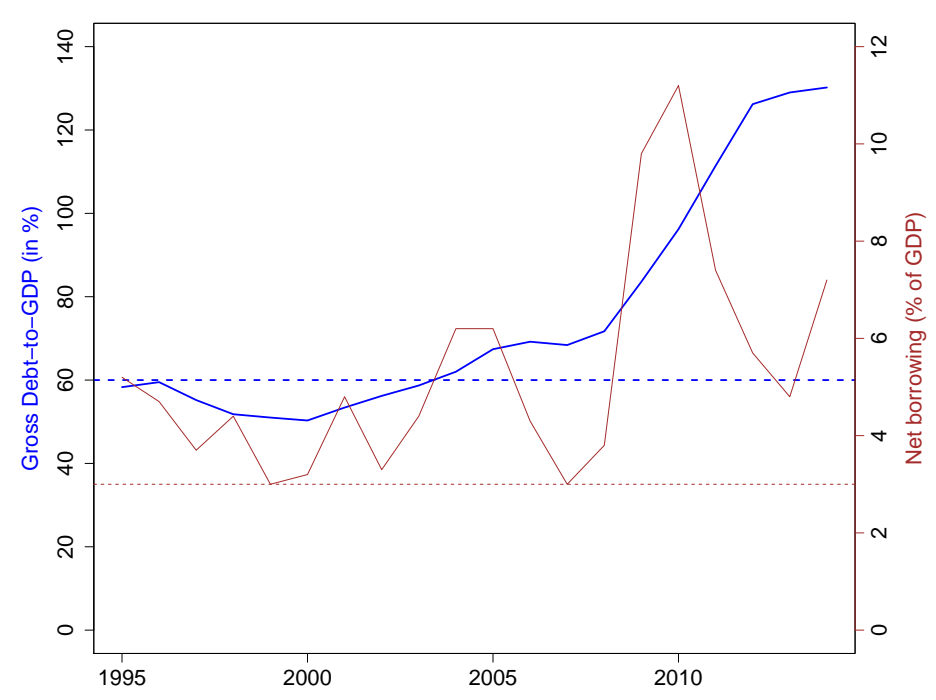

(a) Debt and budget deficit ratios (Data frequency: Annual)

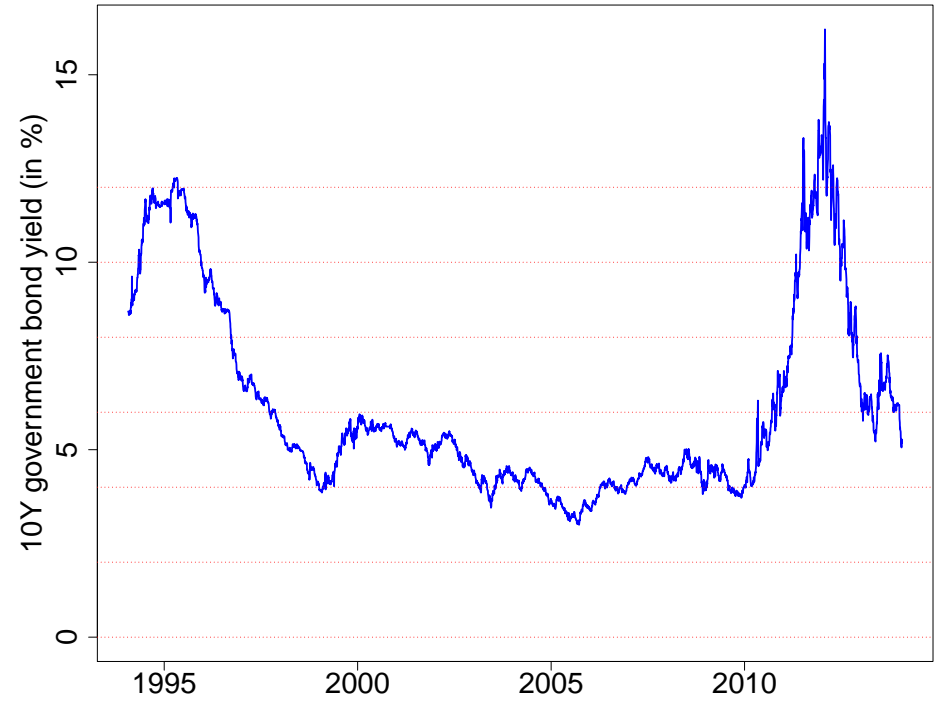

(b) 10Y sovereign yield (Data frequency: Daily) 
Figure 2: $R_{S L}$ vs Money market rate (EONIA)

Source: Bank of Portugal; Frequency: Monthly; Author's calculation. Note: The horizontal line represents the average level of money market rate (brown) and $R_{S L}$ (blue). The vertical red lines from the left represents date at which Lehman Brothers filed for bankruptcy, the official date when Portugal lost market access and the return of Portugal to international debt market.

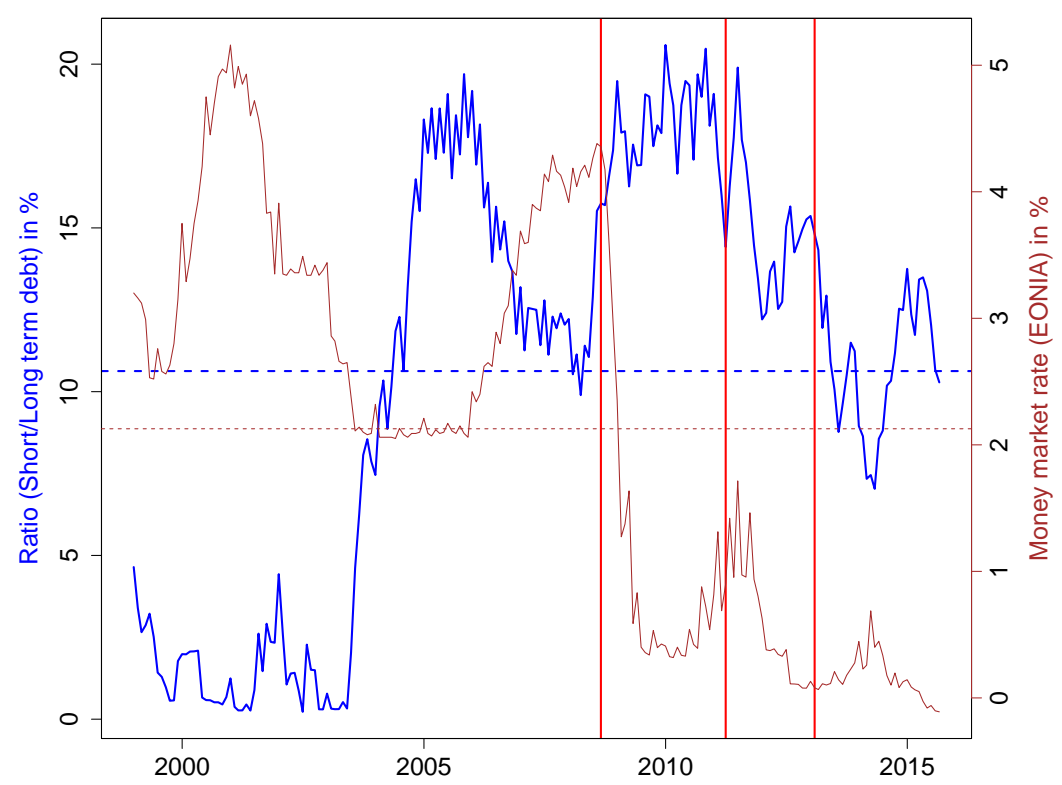


Figure 3: $R_{S L}$ vs 10-year benchmark Portuguese sovereign bond yield Source: Bank of Portugal; Frequency: Monthly; Author's calculation. Note: The horizontal line represents the average level of money market rate (brown) and $R_{S L}$ (blue). The vertical red lines from the left represents date at which Lehman Brothers filed for bankruptcy, the official date when Portugal lost market access and the return of Portugal to international debt market.

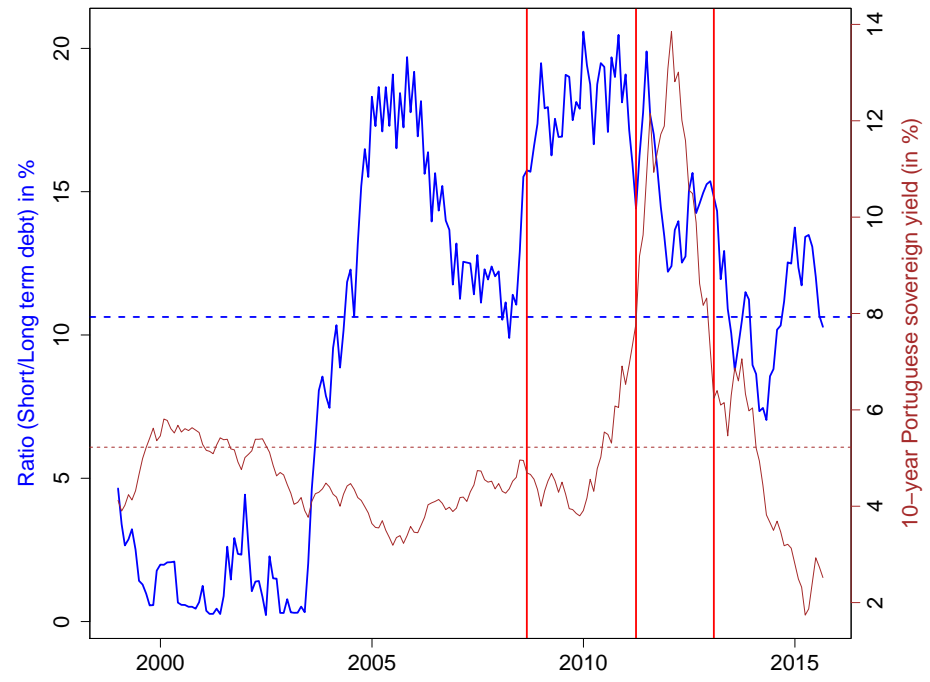


Figure 4: Ratio of short and long-term debt outstanding $\left(R_{S L}\right)$ vs Term premium Source: Bank of Portugal; Frequency: Monthly; Author's calculation. Note: The horizontal line represents the average level of money market rate (brown) and $R_{S L}$ (blue). The vertical red lines from the left represents date at which Lehman Brothers filed for bankruptcy, the official date when Portugal lost market access and the return of Portugal to international debt market.

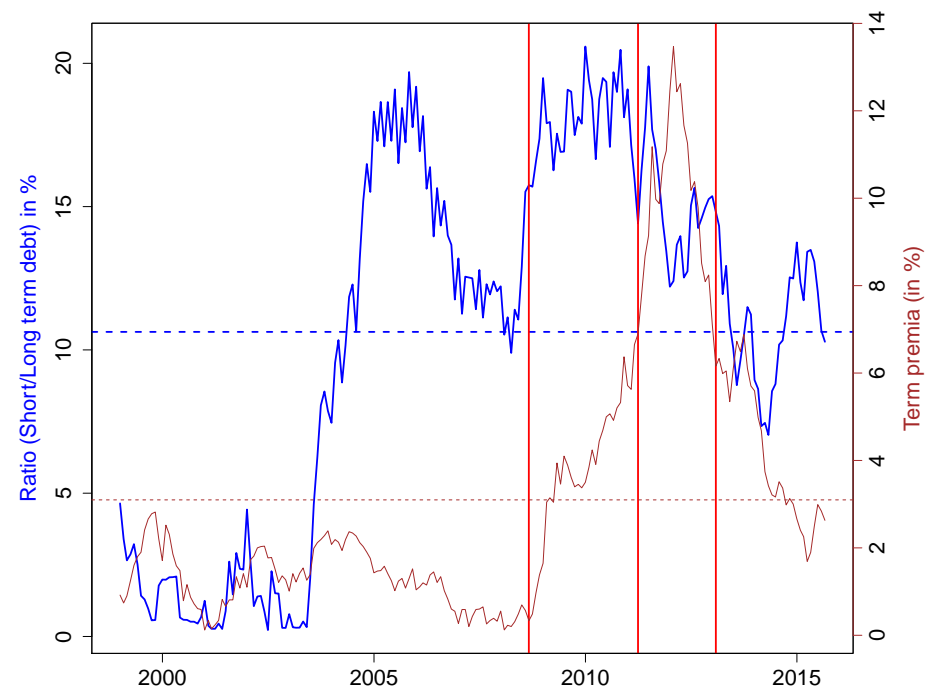


Table 1: Data description

Note: GG - General Government; STD - Short-term debt; LTD - Long-term debt; BoP - Banco de Portugal; EC - EC; INE - Instituto Nacional de Estatística; DGO - Direcção Geral do Orçamento.

\begin{tabular}{lllll} 
Time series name & Source & Power & Unit of measure & Frequency \\
\hline & & & & \\
EONIA & BoP & & Percent & Daily \\
Treasury bond yield $-10 Y$ & BoP & & Percent & Monthly \\
Net issues of GG STD securities & BoP & $10^{6}$ & Euros & Monthly \\
Net issues of GG LTD securities & BoP & $10^{6}$ & Euros & Monthly \\
Gross debt of GG - \% of GDP & DGO and BoP & & Percentage & Quarterly \\
GG gross debt - short-term & BoP & $10^{6}$ & Euros & Quarterly \\
GG gross debt - long-term & BoP & $10^{6}$ & Euros & Quarterly \\
GG Net lending (-) /net borrowing (+) & EuroStat & & Percentage & Quarterly \\
GG Net expenditure (+) /net revenue (-) & EuroStat & & Percentage & Quarterly \\
Non-resident holding of GG debt & BoP & & Percentage & Quarterly \\
Relative debt market size & EuroStat & & Percentage & Monthly \\
\hline
\end{tabular}


Table 2: Summary statistics

Min. 1st Qu. Median Mean 3rd Qu. Max.

\begin{tabular}{lrrrrrr}
$R_{S L}$ & 0.22 & 7.92 & 12.50 & 11.31 & 16.46 & 20.58 \\
EONIA & -0.12 & 0.35 & 2.06 & 1.98 & 3.33 & 5.06 \\
Term Spread & 0.15 & 1.21 & 2.08 & 3.27 & 4.38 & 13.47 \\
Volatility & 6.04 & 11.42 & 15.89 & 21.16 & 26.99 & 109.40 \\
Debt/GDP ratio & 50.10 & 58.70 & 68.85 & 82.09 & 111.40 & 132.80 \\
Primary Deficit & -0.20 & 2.70 & 5.65 & 5.62 & 7.40 & 18.50 \\
Relative Market Size & 1.37 & 1.56 & 1.80 & 1.76 & 1.92 & 2.16 \\
Foreign Debt Holding & 37.61 & 57.23 & 64.97 & 62.96 & 70.97 & 79.70 \\
\hline
\end{tabular}


Table 3: Raw correlations

$\begin{array}{lllllll}(1) & (2) & (3) & (4) & (5) & (6) & (7)\end{array}$

\begin{tabular}{llrrrrrrrrr}
$(1)$ & $R_{S L}$ & 1.00 & & & & & & & \\
$(2)$ & EONIA & -0.53 & 1.00 & & & & & & \\
$(3)$ & Term Spread & 0.33 & -0.70 & 1.00 & & & & & \\
$(4)$ & Volatility & 0.29 & -0.60 & 0.49 & 1.00 & & & & \\
$(5)$ & Debt/GDP ratio & 0.36 & -0.83 & 0.69 & 0.63 & 1.00 & & & \\
$(6)$ & Primary Deficit & 0.40 & -0.45 & 0.33 & 0.25 & 0.26 & 1.00 & & \\
$(7)$ & Relative Market Size & 0.80 & -0.55 & 0.50 & 0.39 & 0.54 & 0.42 & 1.00 & \\
$(8)$ & Foreign Debt Holding & 0.64 & -0.41 & -0.15 & 0.22 & 0.33 & 0.18 & 0.55 & 1.00 \\
\hline
\end{tabular}


Table 4: Baseline estimates for different periods

\begin{tabular}{|c|c|c|c|}
\hline Dependent Variable & Full sample & $\begin{array}{c}\Delta R_{t}^{S L} \\
\text { Pre-crisis period }\end{array}$ & Crisis Period \\
\hline Constant & $\begin{array}{r}1.1407 \\
(0.3569)\end{array}$ & $\begin{array}{r}-2.6448 \\
(0.4027)\end{array}$ & $\begin{array}{r}2.9096 \\
(0.8012)\end{array}$ \\
\hline $\operatorname{EONIA}_{(t-1)}$ & $\begin{array}{r}0.0369 \\
(0.8160)\end{array}$ & $\begin{array}{r}0.9088^{* *} \\
(0.0214)\end{array}$ & $\begin{array}{r}0.0794 \\
(0.8060)\end{array}$ \\
\hline Term Spread $_{(t-1)}$ & $\begin{array}{r}0.1361 \\
(0.1073)\end{array}$ & $\begin{array}{r}0.5357 \\
(0.1974)\end{array}$ & $\begin{array}{r}0.0434 \\
(0.8007)\end{array}$ \\
\hline Volatility $_{(t-1)}$ & $\begin{array}{r}0.0062 \\
(0.4656)\end{array}$ & $\begin{array}{r}0.1058^{* * *} \\
(0.0023)\end{array}$ & $\begin{array}{r}-0.0004 \\
(0.9638)\end{array}$ \\
\hline $\operatorname{Debt}_{/ G D P \text { ratio }_{(t-1)}}$ & $\begin{array}{r}-0.0124^{*} \\
(0.0696)\end{array}$ & $\begin{array}{r}0.2857^{* *} \\
(0.0359)\end{array}$ & $\begin{array}{r}-0.0096 \\
(0.5586)\end{array}$ \\
\hline Primary Deficit $_{(t-1)}$ & $\begin{array}{r}-0.0288 \\
(0.3677)\end{array}$ & $\begin{array}{r}-0.0858^{*} \\
(0.0670)\end{array}$ & $\begin{array}{r}-0.0150 \\
(0.7484)\end{array}$ \\
\hline Relative Market $S_{i z e_{(t-1)}}$ & $\begin{array}{r}-2.0205^{* *} \\
(0.0215)\end{array}$ & $\begin{array}{r}-15.6540^{* * *} \\
(0.0014)\end{array}$ & $\begin{array}{r}-1.7570 \\
(0.5354)\end{array}$ \\
\hline Foreign Debt Holding ${ }_{(t-1)}$ & $\begin{array}{r}0.0477^{* *} \\
(0.0209)\end{array}$ & $\begin{array}{r}0.1106^{* * *} \\
(0.0059)\end{array}$ & $\begin{array}{r}0.0191 \\
(0.7861)\end{array}$ \\
\hline$\Delta R_{(t-1)}^{S L}$ & $\begin{array}{r}-0.2993^{* * *} \\
(0.0000) \\
\end{array}$ & $\begin{array}{r}-0.4716^{* * *} \\
(0.0000) \\
\end{array}$ & $\begin{array}{r}-0.1360 \\
(0.2479) \\
\end{array}$ \\
\hline $\begin{array}{l}\text { R-squared } \\
\text { Adjusted } R^{2} \\
\text { Durbin-Watson } \\
\text { No. of observations }\end{array}$ & $\begin{array}{r}0.1324 \\
0.0925 \\
1.8806 \\
183\end{array}$ & $\begin{array}{r}0.3739 \\
0.3195 \\
1.8711 \\
101\end{array}$ & $\begin{array}{r}0.0538 \\
-0.0498 \\
1.9669 \\
82\end{array}$ \\
\hline
\end{tabular}

Note: $* * * * *$, and ${ }^{*}$ denote significance at the 1,5 , and 10 percent levels, respectively. 
Table 5: Baseline regression with interaction terms

Dependent Variable

Constant

$\operatorname{EONIA}_{(t-1)}$

Term $\operatorname{Spread}_{(t-1)}$

Volatility $_{(t-1)}$

Debt/GDP $(t-1)$

Primary Deficit $(t-1)$

Relative Market Size $(t-1)$

Foreign Debt Holding $(t-1)$

$D U M M Y_{(t-1)}^{C r i s i s}$

$\operatorname{EONIA}_{(t-1)} D U M M Y_{(t-1)}^{\text {Crisis }}$

Termspread $_{(t-1)} D U M M Y_{(t-1)}^{\text {Crisis }}$

Volatility $_{(t-1)} D U M M Y_{(t-1)}^{\text {Crisis }}$

Debt $/ G D P_{(t-1)} D U M M Y_{(t-1)}^{\text {Crisis }}$

Primary Deficit $(t-1) \operatorname{DUMMY} Y_{(t-1)}^{\mathrm{Crisis}}$

Relative Market Size ${ }_{(t-1)} D U M M Y_{(t-1)}^{\text {Crisis }}$

Foreign Debt Holding $_{(t-1)} D U M M Y_{(t-1)}^{\text {Crisis }}$

$\Delta R_{(t-1)}^{S L}$

Adjusted $R^{2}$

Durbin-Watson

No. of observations
(1) (2)

(3)

(4)

$\Delta R_{t}^{S L}$

$(5)$

(6)

(7)

$(9)$

$\begin{array}{rr}1.5125 & 1.7051 \\ (0.2362) & (0.1989) \\ 0.1017 & 0.046 \\ (0.5437) & (0.8141) \\ 0.1420^{*} & 0.1294 \\ (0.0931) & (0.14) \\ 0.0047 & 0.0047 \\ (0.5821) & (0.5851) \\ -0.0162^{* *} & -0.0137 \\ (0.032) & (0.1202) \\ -0.0347 & -0.0346 \\ (0.2832) & (0.2853) \\ -2.4310^{* *} & -2.3812^{* *} \\ (0.0102) & (0.0124) \\ 0.0530^{* *} & 0.0491^{* *} \\ (0.0122) & (0.0274) \\ 0.549 & 0.2684 \\ (0.2364) & (0.697) \\ & 0.1525 \\ & (0.5822)\end{array}$

0.627
$(0.7652)$
0.1738
$(0.4208)$

0.2442
$(0.8568)$

1.7016

$(0.8568) \quad(0.2383)$

0.1618

0.1159

$0.3321) \quad(0.5081)$

$0.112 \quad 0.1553$

0.3116

$(0.3456)$

0.0046

$(0.1824)$

$(0.1089)$

$0.0916^{* * *} \quad 0.0042$

$\begin{array}{lll}0.5886) & (0.0109) \quad(0.6304)\end{array}$

$-0.0137$

(0.1258)

$-0.0325$

(0.3197)

$-2.2701^{* *}$

(0.0224)

$0.0533^{* *}$

(0.0119)

0.8096

$-0.0128^{*}$

-0.0395
$-(0.6302)$

$(0.0909) \quad(0.6302)$
-0.0415

$-0.0415$

(0.194)

$-0.0364$

$(0.2694)$

$-2.1908^{* *}$

$-1.9962$

(0.0192) $\quad(0.2662)$

$0.0438^{* *} \quad 0.0605^{*}$

$(0.0378) \quad(0.0735)$

$(0.2312)$

$1.9479 * *$

$-1.2452$

$(0.0074) \quad(0.8437)$

1.77

(0.173)

0.1035

(0.5361)

$0.1559^{*}$

(0.0684)

0.0051

(0.5477)

$-0.0157^{* *}$

(0.0386)

$-0.0748$

(0.1283)

$-2.6923^{* * *}$

(0.0059)

$0.0576^{* * *}$

(0.0076)

0.1143

(0.8517)

1.9791

(0.1288)

$2.8819^{*}$

(0.0691)

$\begin{array}{ll}0.3106 & 0.0662\end{array}$

$(0.1376) \quad(0.6947)$

$0.2180^{* *}$

$-0.0052$

(0.0234)

0.0019

$(0.8225)$

$-0.0002$

(0.9868)

$-0.0451$

(0.1689)

$-5.4089^{* * *}$

(0.008)

$0.0986^{* * *}$

(0.0047)

$-10.8051$

(0.9681)

0.0058

(0.4979)

$-0.0209^{* *}$

(0.011)

$-0.0358$

(0.2667)

$-3.7939^{* * *}$

(0.0045)

$0.0767^{* * *}$

(0.0041)

7.243

(0.1153)

(0.1164)

$-0.1746$

(0.5951)

$-0.0920^{* *}$

(0.0129)

0.0252

(0.7758)

0.0691

(0.2778)

5.9633*

(0.0973)

$-0.0852$

(0.1446)

$-0.31^{* * *}$

$-0.31^{* * *}$

(0.0000)

(0.0000)

(0.0000)

$\begin{array}{ll}0.1531 & 0.1501 \\ 0.1039 & 0.1006\end{array}$

1.8974

1.8792

183 183

$-2.4874$

(0.4798)

$0.8500^{*}$

(0.0516)

0.4622

(0.3168)

$0.1033^{* * *}$

(0.0069)

$0.2753^{*}$

(0.0678)

$-0.084$

(0.1061)

$-14.8591 * * *$

(0.0055)

$0.1016^{* * *}$

(0.0213)

6.544

$(0.5567)$

$-0.7039$

$(0.1862)$

$-0.4295$

(0.3786)

$-0.1031$

(0.0087)

$-0.2858$

(0.0594)

0.0747

(0.2679)

$12.6172^{* *}$

(0.033)

$-0.0849$

$(0.2757)$

$-0.32^{* * *}$ (0.0000)

\subsection{7}

0.091

0.0909

0.1217

0.0898

0.0956

1.8803

\begin{tabular}{rr}
183 & 183 \\
\hline
\end{tabular}

0.2114

0.1354

1.8975

Note: ${ }^{* * *},{ }^{* *}$, and $*$ denote significance at the 1,5 , and 10 percent levels, respectively. 
Table 6: Two stage least square regression results

Dependent Variable

Constant

$\operatorname{EONIA}_{(t-1)}$

Term Spread $_{(t-1)}$

Volatility $_{(t-1)}$

Debt/GDP ratio $_{(t-1)}$

Primary Deficit ${ }_{(t-1)}$

Relative Market Size $_{(t-1)}$

Foreign Debt Holding ${ }_{(t-1)}$

$\operatorname{Dummy} y_{(t-1)}^{\text {Crisis }}$

$\Delta R_{(t-1)}^{S L}$
$\Delta R_{t}^{S L}$

(1)

\begin{tabular}{rr}
1.4842 & 2.0421 \\
$(0.3463)$ & $(0.2250)$ \\
0.0595 & 0.1149 \\
$(0.7958)$ & $(0.6203)$ \\
0.1830 & $0.1879^{*}$ \\
$(0.1017)$ & $(0.0918)$ \\
0.0191 & 0.0167 \\
$(0.4228)$ & $(0.4906)$ \\
$-0.0193^{* *}$ & $-0.0242^{* *}$ \\
$(0.0643)$ & $(0.0303)$ \\
-0.0540 & -0.0637 \\
$(0.4175)$ & $(0.3481)$ \\
$-2.6623^{* *}$ & $-3.1258^{* *}$ \\
$(0.0301)$ & $(0.0169)$ \\
$0.0644^{* *}$ & $0.0699^{* *}$ \\
$(0.0253)$ & $(0.0172)$ \\
& 0.6368 \\
& $(0.2956)$ \\
$-0.7698^{* * *}$ & $-0.7611^{* * *}$ \\
$(0.0029)$ & $(0.0028)$ \\
\hline & \\
-0.0944 & -0.0774 \\
-0.145 & -0.1338 \\
182 & 182 \\
\hline &
\end{tabular}

Note: $* * *, * *$, and $*$ denote significance at the 1,5, and 10 percent levels, respectively. 
Table 7: Baseline estimates for forward looking debt managers for different periods

Dependent Variable

$\Delta R_{t}^{S L}$

Full sample
$\Delta R_{t}^{S L}$

Pre-crisis period
$\Delta R_{t}^{S L}$

Crisis Period

(1) (2)

Constant

$\operatorname{EONI} A_{(t-1)}$

Term $\operatorname{Spread}_{(t-1)}$

Volatility $_{(t-1)}$

$\operatorname{Debt} / G D P_{(t-1)}$

$\operatorname{EXP}($ Debt/GDP ratio $)$

Primary Deficit $_{(t-1)}$ (2)

(3) (1)

(2)

\begin{tabular}{rrrrrrr}
1.1407 & 1.2985 & 1.4204 & -1.1038 & 0.2108 & -6.6907 & 0.2108 \\
$(0.3569)$ & $(0.3221)$ & $(0.4107)$ & $(0.7896)$ & $(0.9729)$ & $(0.5663)$ & $(0.9729)$ \\
0.0369 & 0.0330 & 0.0376 & 0.7006 & 0.6572 & 0.3301 & 0.6572 \\
$(0.8160)$ & $(0.8413)$ & $(0.8377)$ & $(0.1425)$ & $(0.1769)$ & $(0.3615)$ & $(0.1769)$ \\
0.1361 & 0.1280 & 0.0532 & 0.4761 & 0.4039 & 0.1274 & 0.4039 \\
$(0.1073)$ & $(0.1297)$ & $(0.6270)$ & $(0.3219)$ & $(0.4178)$ & $(0.4491)$ & $(0.4178)$ \\
0.0062 & 0.0049 & 0.0049 & $0.0945^{* * *}$ & $0.0864^{* *}$ & -0.0029 & $0.0864^{* *}$ \\
$(0.4656)$ & $(0.5582)$ & $(0.5720)$ & $(0.0084)$ & $(0.0228)$ & $(0.7608)$ & $(0.0228)$ \\
$-0.0124^{*}$ & & & & & \\
$(0.0696)$ & & & & & \\
& -0.0118 & 0.0054 & 0.0410 & 0.0207 & 0.0079 & 0.0207 \\
-0.0288 & -0.0279 & -0.0340 & $-0.1000^{* *}$ & -0.0810 & -0.0136 & -0.0810 \\
$(0.3677)$ & $(0.3884)$ & $(0.3148)$ & $(0.0351)$ & $(0.1102)$ & $(0.7736)$ & $(0.1102)$ \\
$-2.0205^{* *}$ & $-2.0123^{* *}$ & $-2.3367^{* *}$ & $-7.7941^{* * *}$ & $-8.4327^{* * *}$ & 0.3988 & $-8.4327^{* * *}$ \\
$(0.0215)$ & $(0.0224)$ & $(0.0119)$ & $(0.0081)$ & $(0.0055)$ & $(0.8851)$ & $(0.0055)$ \\
$0.0477^{* *}$ & $0.0451^{* *}$ & $0.0434^{* *}$ & $0.1309^{* * *}$ & $0.1119^{* *}$ & 0.0647 & $0.1119 * *$ \\
$(0.0209)$ & $(0.0284)$ & $(0.0421)$ & $(0.0033)$ & $(0.0234)$ & $(0.3552)$ & $(0.0234)$ \\
& & -0.2094 & & 0.1168 & & 0.1168 \\
& & $(0.1726)$ & & $(0.7714)$ & & $(0.7714)$ \\
$-0.2993^{* * *}$ & $-0.2989^{* * *}$ & $-0.3018^{* * *}$ & $-0.4603^{* * *}$ & $-0.4664^{* * *}$ & -0.1321 & $-0.4664^{* * *}$ \\
$(0.0000)$ & $(0.0000)$ & $(0.0000)$ & $(0.0000)$ & $(0.0000)$ & $(0.2617)$ & $(0.0000)$ \\
\hline & -0.0754 & & 0.3423 & & 0.3423 \\
& & & & &
\end{tabular}

\begin{tabular}{|c|c|c|c|c|c|c|c|}
\hline R-squared & 0.1324 & 0.1272 & 0.1385 & 0.346 & 0.3558 & 0.0515 & 0.3558 \\
\hline Adjusted & 0.0925 & 0.0871 & 0.083 & 0.2891 & 0.2762 & -0.0524 & 0.2762 \\
\hline Durbin-Watson & 1.8806 & 1.8839 & 1.8717 & 1.819 & 1.8299 & 1.9439 & 1.8299 \\
\hline No. of observations & 183 & 183 & 183 & 101 & 101 & 82 & 101 \\
\hline
\end{tabular}

Note: $* * *, * *$, and $*$ denote significance at the 1,5, and 10 percent levels, respectively. 
Table 8: Forward looking debt managers behavior with interactive terms

Dependent Variable

$\Delta R_{t}^{S L}$ 1.5125
$(0.2362)$
0.1017
$(0.5437)$
$0.1420^{*}$
$(0.0931)$
0.0047
$(0.5821)$
$-0.0162^{* *}$
$(0.0320$

$\operatorname{EXP}($ Debt/GDP ratio $)$

Primary Deficit $(t-1)$

Relative Market Size $_{(t-1)}$

Foreign Debt Holding ${ }_{(t-1)}$

$E X P(G D P$ growth rate $)$

EXP(Unemployment rate $)$

EXP(Inflation $)$

$E X P(G D P$ growth rate $) * D$ Dmmy $y^{\text {Crisis }}$

EXP $($ Unemployment rate $) * D u m m y^{\text {Crisis }}$

EXP $($ Inflation $) * D u m m y$ Crisis

$\Delta R_{(t-1)}^{S L}$

$-0.3015^{* * *}$
$-0.0347$

$(0.2832)$

$-2.4310^{* *}$

(0.0102)

0.0530 **

(0.0122)

0.549

(0.2364)
(1)
(2)

(3)

$\begin{array}{rr}1.7052 & 1.9655 \\ (0.2139) & (0.3456) \\ 0.0821 & 0.0656 \\ (0.6325) & (0.7345) \\ 0.1325 & 0.0583 \\ (0.1173) & (0.5972) \\ 0.0034 & 0.0042 \\ (0.6854) & (0.6288)\end{array}$

$-0.0156^{*}$
$(0.0736)$

0.0033

$(0.8629)$

$-0.0334$

$-0.0352$

(0.3082)

(0.2997)

$-2.3618^{* *}$

(0.0127)

$0.0491^{* *}$

(0.0192)

0.4727

(0.3083)

$-2.4274^{* *}$

(0.0107)

$0.0411^{*}$

(0.0614)

$-0.3072$

(0.2355)

$-0.0726$

(0.5038)

0.1505

(0.6046)

0.1335

(0.6383)

(0.0000)

$-0.3011^{* * *}$

$-0.3021^{* * *}$

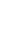

(0.0000)

(0.0000)
(4)

1.3916

(0.4209)

0.0337

(0.8548)

0.0464

(0.6729)

0.0038

(0.6642)

$-0.0355$

(0.2953)

$-2.4864^{* * *}$

(0.0090)

$0.0490^{* *}$

(0.0304)

$-0.1870$

(0.2319)

$-0.0982$

(0.3823)

0.3021

(0.3634)

(0.3634)

0.0466
$(0.4466)$

$-0.3048^{* * *}$

(0.3019)

0.2408

(0.0000)

(0.0000)

\begin{tabular}{rrr}
0.1414 & 0.1439 & 0.1450 \\
0.0808 & 0.0834 & 0.0738 \\
1.8758 & 1.8792 & 1.8802 \\
183 & 183 & 183 \\
\hline
\end{tabular}

(6)
0.1325

0.1396

0.0788

0.0873

1.8747

183

(0.2377)

0.0319

(0.8623)

0.0246
$(0.8277)$

0.0038

0.0007

(0.9721)

$-0.0341$

(0.3121)

$-2.8193^{* * *}$

(0.0069)

0.0459 **

(0.0327)

$-0.1976$

(0.1992)

$-0.0482$

(0.6646)

0.148

(0.6060)

0.0022

(0.9074)

$-0.0317$

(0.3550)

$-3.0877^{* *}$

(0.0103)

0.0417

(0.1425)

$-0.1797$

(0.6128)

0.0116

(0.9484)

$-0.0511$

(0.9321)

$-0.0502$

(0.8990)

$-0.0655$

(0.6875)

0.4967

(0.4003)

$-0.3057 * * *$

183

\subsection{2 \\ (0.9483)}

R-squared

0.1394

1.8804

(0.6620)

Durbin-Watson

183

Note: $* * * * *$, and $*$ denote significance at the 1,5 , and 10 percent levels, respectively. 
Table 9: Forward looking debt managers behavior - 2SLS estimations

\begin{tabular}{|c|c|c|}
\hline Dependent Variable & \multicolumn{2}{|c|}{$\Delta R_{t}^{S L}$} \\
\hline \multirow[t]{2}{*}{ Constant } & 1.8804 & 2.5219 \\
\hline & $(0.2615)$ & $(0.1639)$ \\
\hline \multirow[t]{2}{*}{$\operatorname{EONIA}_{(t-1)}$} & 0.0278 & 0.0667 \\
\hline & $(0.9069)$ & $(0.7796)$ \\
\hline \multirow{2}{*}{$\operatorname{Term~Spread}_{(t-1)}$} & 0.1704 & 0.1729 \\
\hline & $(0.1238)$ & $(0.1172)$ \\
\hline \multirow{2}{*}{ Volatility $_{(t-1)}$} & 0.0142 & 0.0111 \\
\hline & $(0.5294)$ & $(0.6364)$ \\
\hline \multirow[t]{2}{*}{$E X P($ Debt $/ G D P$ ratio $)$} & $-0.0192^{*}$ & $-0.0241^{* *}$ \\
\hline & $(0.0867)$ & $(0.0428)$ \\
\hline \multirow[t]{2}{*}{ Primary Deficit $_{(t-1)}$} & -0.0527 & -0.0621 \\
\hline & $(0.4297)$ & $(0.3608)$ \\
\hline \multirow[t]{2}{*}{ Relative Market Size $(t-1)$} & $-2.6212^{* *}$ & $-3.0320^{* *}$ \\
\hline & $(0.0335)$ & $(0.0204)$ \\
\hline \multirow[t]{2}{*}{ Foreign Debt Holding ${ }_{(t-1)}$} & $0.0599 * *$ & $0.0639 * *$ \\
\hline & $(0.0351)$ & $(0.0264)$ \\
\hline \multirow[t]{2}{*}{$\operatorname{Dummy}_{(t-1)}^{\text {Crisis }}$} & & 0.5878 \\
\hline & & $(0.3342)$ \\
\hline \multirow[t]{2}{*}{$\Delta R_{(t-1)}^{S L}$} & $-0.7786^{* * *}$ & $-0.7710^{* * *}$ \\
\hline & $(0.0030)$ & $(0.0029)$ \\
\hline R-squared & -0.1028 & -0.0879 \\
\hline Adjusted $R^{2}$ & -0.1538 & -0.1448 \\
\hline No. of observations & 182 & 182 \\
\hline
\end{tabular}

Note: $* * * * *$, and $*$ denote significance at the 1,5 , and 10 percent levels, respectively. 